\title{
INTENTION OF ADOPTION OF SOCIAL MEDIA IN PROJECTS
}

\section{INTENÇÃO DE ADOÇÃO DE MÍDIAS SOCIAIS EM PROJETOS}

\section{INTENCIÓN DE ADOPCIÓN DE REDES SOCIALES EN PROYECTOS}

\author{
Alex de Souza Santana \\ PhD em Administraçao - UNINOVE \\ alexsantana.gp@gmail.com \\ https://orcid.org/0000-0001-9675-9115
}

Cristina Dai Prá Martens

Diretora do Programa de Mestrado Profissional em Administração - Gestão de Projetos (MPA-GP), Professora e Pesquisadora no Programa de Pós-Graduação em Administração (PPGA) - UNINOVE cristinadpmartens@gmail.com https://orcid.org/0000-0003-0955-9786

Editor Científico: José Edson Lara

Organização Comitê Científico

Double Blind Review pelo SEER/OJS

Recebido em 08.09.2020

Aprovado em 20.12.2020

\section{(i) (8)}

Este trabalho foi licenciado com uma Licença Creative Commons - Atribuição - Não Comercial 3.0 Brasil 


\begin{abstract}
The use of social media tools can offer benefits to organizations and for project management. It is known that before the actual behavior of adopting a technology, there is a step of intention formation, but, what seems not to be well known is what factors can influence such intention, specifically in the context of projects. To fill this gap we developed this study with the objective of identifying which factors influence the intention of adopting social media in projects. A survey was distributed to project professionals in 24 countries and 5 continents $(n=171)$. After execution of PLS technique, we found three factors that influence the intention of adopting social media in projects (performance expectance, social factor and perceived ease of use), so professionals who want to adopt social media technologies in their project tasks should pay attentions and invest their efforts in these aspects. We also observed that contextual factors could make correlations with the intention of adoption less significant than originally proposed for compatibility and testability dimensions in seminal studies.
\end{abstract}

Keywords: Project Management; Social Media; Web 2.0; Intention of Adoption.

\title{
Resumo
}

A adoção de ferramentas de mídias sociais pode oferecer benefícios para as organizações e para o gerenciamento de projetos. Sabe-se que antes do comportamento de adoção de uma tecnologia, existe uma etapa de formação da intenção, mas, o que parece ainda não ser bem conhecido são justamente os fatores que podem influenciar tal intenção de adoção, especificamente no contexto de projetos. Para preencher essa lacuna desenvolvemos este estudo com o objetivo de identificar quais fatores influenciam a intenção de adoção de mídias sociais em projetos. Um questionário foi distribuído a profissionais de projetos em 24 países em 5 continentes $(n=171)$. Após execução da técnica PLS, identificamos três fatores que influenciam a intenção de adoção de mídias sociais em projetos (expectativa de performance, fatores sociais e a facilidade de uso percebida), portanto, profissionais que desejam promover o uso de mídias sociais em suas tarefas de projetos devem atentar-se em investir seus esforços nestes três aspectos. Complementarmente observamos que o fator contextual pode tornar a correção com a intenção de adoção menos significante do que originalmente proposto para os fatores compatibilidade e testabilidade em estudos seminais.

Palavras-chave: Gerenciamento de Projetos; Mídias Sociais; Web 2.0; Intenção de Adoção.

\section{Resumen}

La adopción de herramientas sociales puede ofrecer beneficios para las organizaciones y para la gestión de proyectos. Se sabe que antes de la adopción de una tecnología, hay una etapa de formación de intención, pero lo que parece no ser conocido son precisamente los factores que pueden influir en dicha intención de adopción, específicamente en el contexto de los proyectos. Para llenar este vacío, desarrollamos este estudio para identificar qué factores influyen en la intención de adoptar las herramientas sociales en los proyectos. Se distribuyó un cuestionario a profesionales de proyecto en 24 países en los 5 continentes $(n=171)$. Después de ejecutar la técnica PLS, identificamos tres factores que influyen en la intención de adoptar las herramientas sociales en los proyectos (rendimiento esperado, factores sociales y facilidad de uso percibida), por lo tanto, profesionales que desean promover el uso de las 
herramientas sociales en sus tareas de proyectos deben invertir sus esfuerzos en estos tres aspectos. Además, observamos que el factor contextual puede hacer que la relación con la intención de adopción sea menos significativa de la que fue propuesta originalmente para los factores de compatibilidad y comprobación en los estudios seminales.

Palabras-clave: Gestión de Proyectos; Herramientas Sociales; Web 2.0; Intención de Adopción.

\section{INTRODUCTION}

Since the beginning of the second millennium, the computational tools have incorporated dynamics and social aspects, based on web platforms, leading to what was named as web 2.0 (O'Reilly, 2005), where the social media tools are included. The social media tools is standing still as relevant theme for the organizations, and they keep growing and are present in many different fields such as education (Harris \& Rea, 2019), marketing (Mariani, 2020), and management practices (Orenga-Roglá \& Chalmeta, 2019). The use of social media tools can potentially offer benefits to organizations, such as use of collective intelligence for decision-making, productivity gain, virtual collaboration, cost reduction and processes modeling (Bonabeau, 2009; Filev, 2008; Kosalge \& Tole, 2010). Naturally, project management is one the fields that can benefit from the use of social media.

In organizations, due to the constant change in the environment in which they operate, it has stimulated changes in the field of project management, as a way to respond effectively to such volatility (Ribeiro \& Pedron, 2018). Project management then has a set of peculiarities: decentralized communication, the organization outlined in a network instead of the strong bureaucratic hierarchy structure, the project with flexible and incremental scope to absorb the changes arising from dynamic, global and fast markets and businesses, in addition to increasingly virtual work models and a new profile of human resources and their understanding of work. It was then realized that project management now has the challenge of stimulating a new generation that favors sensory interaction, lived on the internet and literate with the web, and that has new requirements (such as "fun" work environments) and has different skills (Ribeiro \& Pedron, 2018).

It is already known that the effectiveness of technologies is not only dependent on technical aspects (Denyer, Parry, \& Flowers, 2011), so it gives us a sense that there is a need for more research exploring business actors' motivations to adopt new digital technologies (such as social media). Based on the principles of the theories of reasoned action - TRA (Fishbein \& Ajzen, 1975) and planned behavior - TPB (Ajzen, 1991), we must consider that 
before the actual behavior of adopting the social media tools, as well as any other digital technology, there is a dimension of intention of adoption, which can be triggered or influenced by different factors. However, researches exploring the factor that may influence the intention of adoption of social media does not seem to be well addressed in the literature, both specifically in the context of projects or even in completely organizational context.

In addition to the TRA and TPB, there are other theories about the adoption of technologies that can help us to answer what are some of the factors that may influence the intention of adopting social media in projects. However, not all dimensions considered in the existing literature present high significance, and therefore, we propose a framework integrating the most relevant dimensions from each work. By doing this, we suppose to reach our objective of identifying which factors influence the intention of adopting social media in projects.

The proposed framework was empirically validated through the application of structural equations modeling with use of partial least square. The data were collected through the application of a survey with project professionals, distributed in 24 countries. We identified three factors that influence the intention of adopting social media in projects: performance expectance, social factors and perceived ease of use. We also observed that contextual factors could make correlations with the intention of adoption less significant than originally proposed in seminal literatures, specifically the compatibility and testability dimensions.

It is important to note that this study focuses specifically on the process of forming the intention to adopt social media tools for the execution of project-related tasks; that is, we do not consider the adoption behavior itself. In addition, given the exponential number of existing social media applications, the tool itself is not important for the study, but rather for meeting the general characteristics of social media.

Our findings suggest that the more the individual realizes that social media will help him improve his performance in projects tasks, the more he/she intends to adopt them. Therefore, this is the main point that could be handled by leaders who wish to adopt social media in their project tasks, we mean; they should focus their efforts on publicizing the potential benefits of social media to accomplish project tasks. We also found that the more standardized, intuitive, and simplified the operation of social media, the more secure and comfortable users will feel in applying it. Finally, we suggest that a good strategy for adopting 
social media in projects could naturally focus on the individuals that are a reference for the project team in order to influence the intention of their admirers/followers. The compatibility and testability factors did not demonstrate a significant influence on the intention to adopt social media, as opposed to what Rogers (2003) suggests in the innovation diffusion theory, perhaps because of factors related to the context of projects.

We present in the next section the applicable theories in studies of the adoption of new technologies that we used as a base to develop the proposed framework. Next, we present the procedures used for data collection, as well as the statistical techniques used for framework validation. In the fourth section, we discuss the results obtained, and finally, in the last section, we promote a general discussion of the results found and contrast them with the existing literature.

\section{LITERATURE REVIEW AND HYPOTHESIS}

The application of IT in the organizational context and its intention of adoption has been a recurrent focus of studies in the administration and technology fields. Several theories consolidated in literature are applicable to studies of this nature, and a few of them are in Table 1.

\section{Table 1}

Applicable theories in the studies of intention of adoption of new technologies

\begin{tabular}{|l|l|}
\hline Theory & References \\
\hline Reasoned action (TRA) & (Fishbein \& Ajzen, 1975) \\
\hline Social cognitive (SCT) & (Bandura, 1986) \\
\hline Technology acceptance model (TAM) & (Davis, 1989) \\
\hline Planned behavior (TPB) & (Ajzen, 1991) \\
\hline Personal computer utilization model (PCUM) & $\begin{array}{l}\text { (Thompson, Higgins, \& Howell, 1991; Triandis, } \\
1977)\end{array}$ \\
\hline Motivational Model (MM) & $\begin{array}{l}\text { (Davis, Bagozzi, \& Warshaw, 1992; Vallerand, } \\
1997 ; \text { Venkatesh \& Speier, 1999) }\end{array}$ \\
\hline Combined TAM and TPB (C-TAM-TPB) & (Taylor \& Todd, 1995) \\
\hline Technology readiness index (TRI) & $\begin{array}{l}\text { (Parasuraman, 2000; Parasuraman \& Colby, } \\
2001)\end{array}$ \\
\hline Technology acceptance model 2 (TAM2) & $\begin{array}{l}\text { (Venkatesh \& Davis, 2000)Venkatesh \& Davis, } \\
\text { 2000 }\end{array}$ \\
\hline Innovation diffusion (IDT) & (Rogers, 2003) \\
\hline $\begin{array}{l}\text { Unified theory of acceptance and use of technology } \\
\text { (UTAUT) }\end{array}$ & (Venkatesh, Morris, Davis, \& Davis, 2003) \\
\hline
\end{tabular}


We delve into the eleven applicable theories in the study of the intention to adopt new technologies (Table 1) and adopted the following criteria to choose the dimensions that could compose the conceptual model that we propose in this study, along with the basis of the hypotheses that will be raised here: a) the dimensions (in each theory) that were directly pointed to the intention of adoption; b) those (dimensions) with empirically-verified high correlation significance. So, the following dimensions where selected: UTAUT's performance expectance; IDT's compatibility and testability; PCUM's social factors; and TAM's/TAM2 perceived ease of use. We made only the necessary adjustments to adapt to the context (projects) and the technology in subject (social media).

\subsection{Exploring UTAUT}

Its authors (Venkatesh et al., 2003) stated that four aspects had a direct influence on the acceptance and use of technology: performance expectancy, effort expectancy, social influence and facilitating conditions. Four other aspects had a moderating role in the proposed model: the gender (for performance expectancy, effort expectancy and social influence); the age (for all dimensions); the experience (for effort expectancy, social influence and the facilitating conditions); and finally, the voluntariness of use (for social influence). However, in its empirical validation, only the performance expectancy presented a high significant level of influence in the intention to adopt.

Performance expectancy is related to the users' perception of how much technology will help them improve the performance of their tasks (Venkatesh et al., 2003). Therefore, it is expected that the more the users perceives an improvement in the performance of their project tasks with the use of social media, the greater will be their intention to use it, thus giving rise to the first hypothesis of the study:

Hypothesis 1. Performance expectancy positively influences the intention of adopting social media in projects.

\subsection{Exploring IDT}

Since its proposition in 1962, IDT has been explored in diverse contexts such as engineering, medicine, technology, education, sociology, marketing, agriculture, and services. The IDT focus lies in the formation of the individual's attitude and its consequence in the adoption or rejection of an innovation. Innovation is understood as any practice, object, or 
idea perceived as new by an individual or industry. According to its author (Rogers, 2003), this theory comprises five dimensions: relative advantage, compatibility, complexity, visibility of results, and testability. Of these five dimensions, only compatibility and testability meet the criteria established for our study.

Compatibility can be understood as the degree to which the technology is consistent with the users' values, needs and experiences (Rogers, 2003). Thus, it is expected that the more the users realizes that social media is compatible with their values, their needs, and experiences, the greater their intention to use social media in their project tasks. This is the second hypothesis of the study:

Hypothesis 2. Compatibility positively influences the intention of adopting social media in projects.

The testability refers to the possibility of experiencing the potential technology about to be adopted, including assessing additional conditions such as reverting operational actions performed, as well as the costs and risks involved in experimentation processes (Rogers, 2003). It is hoped that the more the users are able to test the social media before applying it directly to their project tasks, the greater will be their intention to effectively use social media in their project tasks. So, the third hypothesis of this study is proposed:

Hypothesis 3. Testability positively influences the intention of adopting social media in projects.

\subsection{Exploring PCUM}

According to their authors (Thompson et al., 1991), the PCUM has as main constructs: a) the adjustment to work, which focuses on the degree of how much the users believe they can improve their work; b) complexity, said to be the perceived degree of difficulty in learning and using technology; c) the long-term consequences, which are defined as results that will have some kind of future compensation; d) affection to the use, that treats the diverse feelings associated to the individual; e) social factors, which evidence the cultures and subjective references of a social group internalized by its members; and f) the facilitating conditions, which are related to the individual's perception of the facilities to perform a given action. In the present study, we focus specifically on social factors, to fully meet the criteria defined for the composition of the conceptual model of our research.

Social factors are the result of users' internalization to the subjective culture of their reference group and the interpersonal covenants created by them in specific social situations 
(Thompson et al., 1991). Thus, it is expected that the subjective norms in their work environment positively influence the intention of the individuals to use social media in projects. Below, the fourth hypothesis is stated:

Hypothesis 4. Social factors positively influence the intention of adopting social media in projects.

\subsection{Exploring TAM/TAM2}

TAM is a theory applicable in any context that involves the interaction between people and technological resources. It had its origins in the studies of Davis and collaborators in the year of 1989. According to definition of its authors, it basically consists of two great dimensions: a) perceived utility; and b) perceived ease of use. TAM was extended in 2000 by Venkatesh et al., where perceived ease of use became a direct determinant of perceived utility.

Perceived ease of use is understood as the users' perception of level of effort that will be required to learn and use the technology (Davis, Bagozzi, \& Warshaw, 1989). It is hoped that the easier it is for users to perceive that they will have an easier time learning and using social media, the more they intend to use them in projects, providing a basis for the fifth hypothesis of this study:

Hypothesis 5. The perceived ease of use positively influences the intention of adopting social media in projects.

\subsection{Proposed conceptual model}

Given the five hypotheses that are under investigation in this study, we then graphically illustrate the resulting conceptual model in Figure 1. 


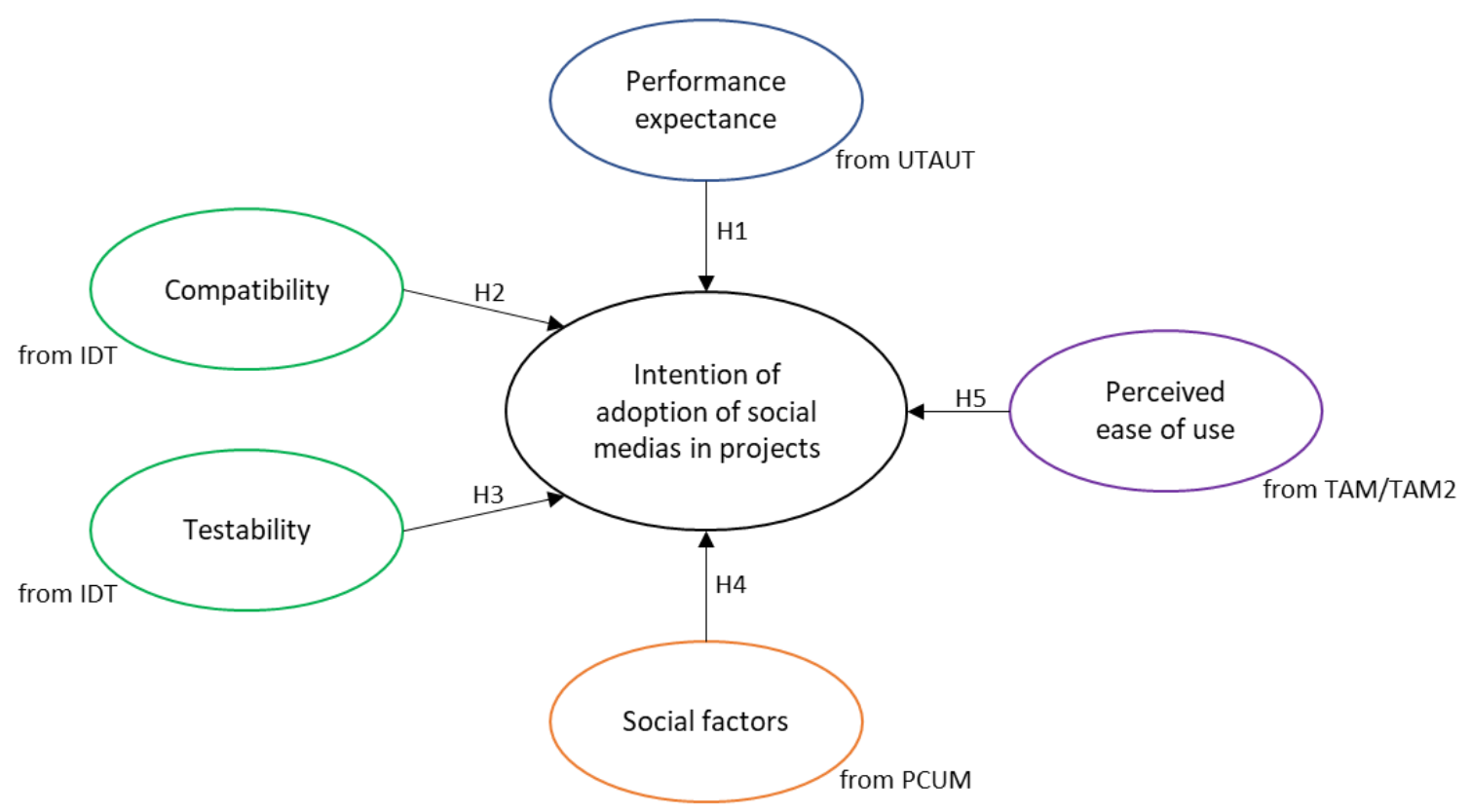

Figure 1. Proposed Research Framework

\section{METHOD}

\subsection{Data collection instrument}

The data were collected through a survey, with a questionnaire made available and created electronically in the Sphinx software (Freitas, Janissek-Muniz, Costa, Andriotti, \& Freitas, 2009). The minimum sample size required was calculated through $\mathrm{G}^{*}$ Power software (Faul, Erdfelder, Buchner, \& Lanf, 2009), resulting in a minimum required sample of 138 individuals, considering the effect size parameters $\mathrm{f}^{2}=0.15$, power $=0.95$ and 5 predictors.

The questionnaire was available for access via Sphinx web server for two months of the second half of 2016. During this period, fifty standard e-mails were daily sent with the name of the recipient and information about the research, within the access link. Exactly 305 people started the questionnaire, of which 68 did not work in projects, seven had never had contact with social media, and 59 did not complete the questionnaire, resulting in 171 valid respondents, which were the basis for data analysis.

\subsection{Measurement scales}

In Table 2, the scales were based on the original validated scales (Davis et al., 1989; Moore \& Benbasat, 1991; Thompson et al., 1991; Venkatesh et al., 2003, 2003), while the questions were only adapted to the research context. The questionnaire also addressed demographic issues. All questions where randomized inside the same subgroup. The variables 
were measured using a 5-point Likert scale (Likert, 1932), ranging from "totally disagree" to "strongly agree", corresponding to the values 1 to 5 respectively.

Table 2

Variables used for measurement

Performance expectance - ED [adapted from Venkatesh et al. (2003)]

ED1 - I would find social media technologies useful in my job

ED2 - Using social media technologies would eanble me to accomplish my projects tasks more quickly

ED3 - Using social media technologies would increase my productivity

ED4 - Using social media technologies would improve the quality of the work I do in the projects

ED5 - Using social media technologies would make easier to do my projects tasks

ED6 - Using social media Technologies would enhance my effectiveness on the project tasks

Compatibility - CO [adapted from Moore and Benbasat (1991)]

CO1 - Using social media technologies is compatible with all aspects of my work

$\mathrm{CO} 2$ - I think that using social media technologies fits well with the way I like to work

CO3 - Using social media technologies fits into my work style

CO4 - Using social media technologies is completely compatible with my current situation

Testability - TE [adapted from Moore and Benbasat (1991)]

TE1 - I've had a great deal of opportunity to try social media technologies

TE2 - I know where (processes/tasks) I can satisfactorily try out various uses of social media

TE3 - Before deciding whether to use any social media technologies, I wish I could properly try them out

TE4 - I am able to experimente social media technologies as necessary

Social factors - FS [adapted from Thompson et al. (1991)]

FS1 - I would use social media technologies because of the proportion of coworkers who use them

FS2 - The senior management has been helpful in the use of social media technologies

FS3 - My superior is very supportive of the use of social media technologies

FS4 - In general, the organization has supported the use of social media technologies

Perceived ease of use - FU [adapted from Davis et al. (1989)]

FU1 - Learning to operate social media technologies would be easy for me

FU2 - I would find it easy to get the social media technologies to do what I want them to do

FU3 - My interaction with the social media technologies would be clear and understandable

FU4 - I would find the social media technologies to be flexible to interact with

FU5 - It would be easy for me to become skillful at using the social media technologies

FU6 - I would find the social media technologies easy to use

Intention of adoption of social media in projects - IU [adapted from Venkatesh et al. (2003)]

IU1 - I intend to use the social media technologies in my projects tasks

IU2 - I predict I would use the social media technologies in my projects tasks

IU3 - I plan to use social media technologies in my project tasks.

\subsection{Characterization of the sample}

The population was composed of members of project teams and project managers. For the data collection, the questionnaire was published on social media (LinkedIn and Facebook), in corporate intranets in which the authors had authorization and by random direct personal indications of project professionals. Most respondents were Brazilian (41\%), while all others were divided into 24 different countries, from five continents. Males accounted for $67 \%$ of the sample. The age of the respondents ranged from 20 to 68 years, with the majority being between 30 and 39 years old (41\%) and 40-49 years old (28\%). The average 
respondent's experience in projects was between ten and fourteen years, with only $17 \%$ of valid respondents having less than five years of experience, which means that the survey had a sample of respondents with considerable experience in the subject. Complementarily, a little more than half affirmed to work in a large company, with more than 1000 employees and with approximate average annual revenue greater than U\$ 100 million.

\subsection{Data analysis techniques}

The adopted method was structural equations modeling (Hair, Hult, Ringle, \& Sarstedt, 2013), which is a multivariate method of statistical analysis, including the partial least squares (PLS) technique, also applied. The collected data were tabulated and imported into the SmartPLS software, in which the conceptual and measurement model was constructed. We guarantee the convergent validity of the framework, observing the Average Variance Extracted - AVEs (Fornell \& Larcker, 1981). The internal consistency values were then evaluated using the Cronbach Alpha indicator (Hair et al., 2013). The next step was to assess the discriminant validity, in order to verify the independence between the constructs (Hair et al., 2013).

We performed the analysis in relation to Pearson's coefficient of determination $\left(\mathrm{R}^{2}\right)$, in order to evaluate the portion of the variance explained by the structural model, thus indicating the final quality of the adjusted model. The significance of the relationships ( $p<=0.05$ ) was evaluated in parallel, and the bootstrapping method was applied (Hair et al., 2013). The parameters adopted for bootstrapping were: 1.000 subsamples, significance of 0.05 , and individual changes for sign changes.

\section{RESULTS}

Following the first step of the defined methodological procedure, it was observed that the Testability obtained unsatisfactory AVE (=0.475). AVE values had to be greater than 0.50, so that convergent validity can be considered satisfactory (Fornell \& Larcker, 1981). It can be observed in Table 3 that TE3 was the best candidate to be excluded from the model, because it had the lowest factor load in the group (=0.328). Therefore, we excluded this variable to perform a new calculation. 
Table 3

Testability factor loads after first run

\begin{tabular}{|c|c|}
\hline Variable & Loading Factor \\
\hline TE1 & 0,786 \\
\hline TE2 & 0,805 \\
\hline TE3 & 0,328 \\
\hline TE4 & 0,727 \\
\hline
\end{tabular}

Table 4 shows resulting AVEs, where the criteria for Fornell and Larcker are met. The values of internal consistency were evaluated using the Cronbach Alpha index, values were considered satisfactory, above 0.70 (Hair et al., 2013), as shown on Table 5.

Table 4

Resulting AVEs

\begin{tabular}{|l|c|}
\hline Construct & AVE \\
\hline Performance expectance (ED) & 0,753 \\
\hline Compatibility (CO) & 0,672 \\
\hline Testability (TE) & 0,623 \\
\hline Social factors (FS) & 0,611 \\
\hline Perceived ease of use (FU) & 0,686 \\
\hline Intention of use (IU) & 0,623 \\
\hline
\end{tabular}

\section{Table 5}

Internal Consistency Validity

\begin{tabular}{|l|l|}
\hline Construct & Cronbach Alpha \\
\hline Performance expectance (ED) & 0,934 \\
\hline Compatibility (CO) & 0,836 \\
\hline Testability (TE) & 0,698 \\
\hline Social factors (FS) & 0,776 \\
\hline Perceived ease of use (FU) & 0,909 \\
\hline Intention of use (IU) & 0,927 \\
\hline
\end{tabular}

The discriminant validity was guaranteed, observing that the factorial load in each respective construct presented a higher value than the others (Hair et al., 2013), as shown in Table 6.

Table 6

Discriminant Validity

\begin{tabular}{|c|c|c|c|c|c|c|}
\hline & CO & ED & FU & FS & IU & TE \\
\hline CO1 & 0,673 & 0,388 & 0,122 & 0,237 & 0,330 & 0,278 \\
\hline CO2 & 0,894 & 0,695 & 0,365 & 0,301 & 0,544 & 0,362 \\
\hline CO3 & 0,891 & 0,610 & 0,301 & 0,356 & 0,539 & 0,339 \\
\hline CO4 & 0,801 & 0,477 & 0,157 & 0,371 & 0,394 & 0,370 \\
\hline ED1 & 0,582 & 0,804 & 0,399 & 0,363 & 0,578 & 0,264 \\
\hline ED2 & 0,602 & 0,880 & 0,316 & 0,297 & 0,538 & 0,325 \\
\hline ED3 & 0,623 & 0,898 & 0,307 & 0,378 & 0,609 & 0,386 \\
\hline ED4 & 0,578 & 0,847 & 0,317 & 0,385 & 0,597 & 0,303 \\
\hline ED5 & 0,585 & 0,900 & 0,396 & 0,334 & 0,608 & 0,306 \\
\hline
\end{tabular}




\begin{tabular}{|l|c|c|c|c|c|c|}
\hline & CO & ED & FU & FS & IU & TE \\
\hline ED6 & 0,569 & 0,875 & 0,354 & 0,364 & 0,576 & 0,326 \\
\hline FS1 & 0,223 & 0,218 & 0,149 & 0,509 & 0,199 & 0,134 \\
\hline FS2 & 0,298 & 0,325 & 0,136 & 0,865 & 0,353 & 0,333 \\
\hline FS3 & 0,342 & 0,386 & 0,189 & 0,855 & 0,406 & 0,199 \\
\hline FS4 & 0,331 & 0,323 & 0,186 & 0,840 & 0,336 & 0,229 \\
\hline FU1 & 0,217 & 0,301 & 0,814 & 0,044 & 0,298 & 0,275 \\
\hline FU2 & 0,148 & 0,273 & 0,787 & 0,145 & 0,280 & 0,322 \\
\hline FU3 & 0,318 & 0,376 & 0,856 & 0,204 & 0,380 & 0,349 \\
\hline FU4 & 0,322 & 0,360 & 0,827 & 0,142 & 0,382 & 0,314 \\
\hline FU5 & 0,249 & 0,302 & 0,818 & 0,228 & 0,390 & 0,241 \\
\hline FU6 & 0,247 & 0,364 & 0,868 & 0,231 & 0,464 & 0,263 \\
\hline IU1 & 0,528 & 0,654 & 0,499 & 0,378 & 0,944 & 0,406 \\
\hline IU2 & 0,519 & 0,606 & 0,448 & 0,397 & 0,937 & 0,360 \\
\hline IU3 & 0,539 & 0,631 & 0,314 & 0,422 & 0,923 & 0,395 \\
\hline TE1 & 0,334 & 0,273 & 0,244 & 0,212 & 0,340 & 0,810 \\
\hline TE2 & 0,367 & 0,355 & 0,284 & 0,243 & 0,360 & 0,837 \\
\hline TE4 & 0,262 & 0,231 & 0,315 & 0,240 & 0,274 & 0,717 \\
\hline
\end{tabular}

The levels of significance of each construct in relation to the intention of adoption are presented in the Table 7, after we ran a bootstrapping, parameterized in 1000 subsamples. The adjusted final model had explanatory power of $54 \%$ (adjusted $\mathrm{R}^{2}=0.539$ ).

Table 7

Correlation's Significances

\begin{tabular}{|l|l|l|l|l|l|}
\hline Hypothesis & $\begin{array}{l}\text { Original } \\
\text { Sample (O) }\end{array}$ & $\begin{array}{l}\text { Sample Mean } \\
(\mathbf{M})\end{array}$ & $\begin{array}{l}\text { Standard } \\
\text { Deviation }\end{array}$ & $\begin{array}{l}\text { Standard Error } \\
\text { (STERR) }\end{array}$ & $\begin{array}{l}\text { T Statistic } \\
\text { (O/STERR) }\end{array}$ \\
\hline H1 (PE-> IU) & 0,422 & 0,415 & 0,080 & 0,080 & 5,220 \\
\hline H2 (CO->IU) & 0,128 & 0,133 & 0,073 & 0,073 & 1,753 \\
\hline H3 (TE->IU) & 0,104 & 0,119 & 0,065 & 0,065 & 1,591 \\
\hline H4 (SF->IU) & 0,136 & 0,142 & 0,059 & 0,059 & 2,222 \\
\hline H5 (PU->IU) & 0,177 & 0,176 & 0,079 & 0,079 & 2,281 \\
\hline
\end{tabular}

Then, based on the statistical results, we conclude that of five hypotheses raised in the study, three were successfully accepted. However, two were rejected because they did not meet satisfactory levels of significance (T Statistic were lower than 1,960). We summarize in Table 8 the accepted and rejected hypotheses, leading to the next section, the respective discussion of the results based on literature. 
Table 8

Accepted and Rejected Hypothesis

\begin{tabular}{|l|l|}
\hline Hypothesis & Results \\
\hline $\begin{array}{l}\text { Hypothesis 1. Performance expectancy positively influences the } \\
\text { intention of adopting social media in projects. }\end{array}$ & Accepted \\
\hline $\begin{array}{l}\text { Hypothesis 2. Compatibility positively influences the intention of } \\
\text { adopting social media in projects. }\end{array}$ & Rejected \\
\hline $\begin{array}{l}\text { Hypothesis 3. Testability positively influences the intention of } \\
\text { adopting social media in projects. }\end{array}$ & Rejected \\
\hline $\begin{array}{l}\text { Hypothesis 4. Social factors positively influence the intention of } \\
\text { adopting social media in projects. }\end{array}$ & Accepted \\
\hline $\begin{array}{l}\text { Hypothesis 5. The perceived ease of use positively influences the } \\
\text { intention of adopting social media in projects. }\end{array}$ & Accepted \\
\hline
\end{tabular}

\section{DISCUSSION}

\subsection{Findings}

Results agreed with Venkatesh et al (2003); that is, the more the users realize that technology will help them improve their performance in project tasks, the more them intends to adopt the technology. Therefore, this is one of the points that could be handled by leaders who wish to adopt social media in their project tasks. One possible way to improve the users' perception of performance expectancy may be to focus on the potential aspects suggested by Filev (2008), such as improvement in the efficiency of the daily activities of the managers, the time savings, and productivity gain.

Another important observed factor is that the more the users perceive that it will not be necessary to spend much effort to learn how to operate the technology and apply it at work, the greater his/her intention to adopt it. This result confirms what Davis et al (1989) pointed out, with regard to perceived ease of use. Thus, we can suggest to application developers who want to create social applications for projects, that they also should address the needs of potential users, especially regarding the level of ease of perceived use, which is important for the purpose of adoption. We understand that the more standardized, intuitive and simplified the operation of social media, the more secure and comfortable users will feel in applying it.

We have identified that social factors also positively influence the intention to adopt social media in projects. This factor is in line with what Thompson et al (1991) argued; that is, there is a subjective internalization by the users to their reference group and to the interpersonal agreements created by them in specific social situations. Therefore, the more individuals who are references in the project team make use of or appreciate social media, the 
greater the possibility that the other members will also intend to adopt them. We suggest that a good strategy for adopting social media in projects could naturally focus on the individuals that are a reference for the project team, aiming to influence the intention of their admirers/followers.

The compatibility and testability factors did not demonstrate a significant influence on the intention to adopt social media, as opposed to what Rogers (2003) suggests in the innovation diffusion theory. In the case of testability, we suggest that the contextual factor can change the influence relation since in a project environment the team members do not have many opportunities to perform tests, due to the constant pressure of time. A research made by Khedhaouria et al (2017), for example, found that learning orientation and knowledge sourcing behaviors play a central role in reducing team members' experience of time pressure and in fostering their creativity.

Regarding the non-significance of the compatibility factor, we refer to a study carried out by Liang et al (2012), which verified the impact of diversity on IT projects, and we come to the understanding that the projects are in fact environments with great diversity, which impacts several aspects, including performance. It is possible that, in this study, the nonadoption of control or moderation variables reflecting the diversity of respondents (who are project workers) may have influenced the significance of the relationship between compatibility and intention to adopt.

\subsection{Limitations of this study}

We must recognize that there is a limitation in this study, regarding the consideration of variables that could moderate the relation of the compatibility with the intention of adoption. This is further reinforced when we consider that the average age of the sample obtained was relatively high and predominantly male. We were not also able to consider the adaptations in the organizational structure as possible precursors of technology adoption in emerging fields.

\subsection{Future research}

In addition to exploring variables that can moderate the relation of the dimensions proposed in the conceptual model, future studies could also explore other variables inherent to the context, extending the practical and theoretical contributions of this study, such as the level of virtualization of teams or organizational. Globalization has increased multinational organizations' reliance on global virtual teams (GVTs) to facilitate collaboration across dispersed employees and stakeholders (Zander, Mockaitis, \& Butler, 2012). GVTs typically 
consist of interdependent groups of individuals who reside in different time zones and countries and who rely primarily on communication technology or media to accomplish a common goal (Horwitz, Bravington, \& Silvis, 2006; O’Leary \& Cummings, 2007). Virtualization of teams is a real phenomenon that depends on communication tools; therefore, there should be nuances that can contribute even more to the understanding of the intention to adopt social media in projects. Futher longitudinal or qualitative studies could also explore the adaptations in the organization structure as important precursors of technology adoption as once suggested by Khanagha et al (2013).

\section{FINAL CONSIDERATIONS}

This article aimed to identify factors that influence the intention of adopting social media in projects. Based on the results achieved, we can suggest that to promote the use of social media in project tasks, it is necessary to focus mainly on the users' performance expectancy in relation to social media, by demonstrating to them the usefulness of technology for their projects tasks, productivity gain and efficiency. Two other important factors to consider are: perceived ease of use, which is naturally understood that the more standardized, intuitive and simplified the operation of social media to use, the more comfortable the user will feel in applying it; the social factors, which are understood as the more project professionals perceive a clear interest in social media in the environment in which they work, the more secure and motivated to use them they will be.

The present research has practical contribution since it has resulted in the identification of some factors that influence the intention of adopting social media in project tasks, allowing managers to identify more easily where in fact to invest their efforts to better extract the expected benefits from the use of such technologies. In addition, information technology professionals can consider the needs of potential users, especially regarding the level of perceived ease of use, which is important for the intention of adoption purpose.

In theoretical terms, the resulting conceptual model presented $54 \%$ of explanatory power, validated empirically. Here we encourage new studies to advance, allowing project management, which is an important discipline for achieving strategic organizational goals, to benefit more and more from the resources offered by social media, which are increasingly present in the daily life. 


\section{REFERENCES}

Ajzen, I. (1991). The theory of planned behavior. Organizational behavior and human decision processes, 50(2), 179-211.

Bandura, A. (1986). Social foundation of thought and action: a social cognitive theory. Englewoords Cliffs, NJ, US: Prentice-Hall.

Bonabeau, E. (2009). Decisions 2.0: the power of collective intelligence. MIT Sloan Management Review, 50(2), 45.

Davis, F. (1989). Perceived usefulness, perceived ease of use, and user acceptance of information technology. MIS Quarterly, 13, 319-340.

Davis, F., Bagozzi, R., \& Warshaw, P. (1989). User acceptance of computer technology: a comparison of two theoretical models. Management Science, 35(8), 982-1003.

Davis, F., Bagozzi, R., \& Warshaw, P. (1992). Extrinsic and intrinsic motivation to use computers in the workplace. Journal of Applied Social Psychology, 22(14), 1111-1132.

Denyer, D., Parry, E., \& Flowers, P. (2011). "Social", "Open" and "Participative"? Exploring personal experiences and organisational effects of enterprise 2.0 use. Long Range Planning, 44(5-6), 375-296.

Faul, F., Erdfelder, E., Buchner, A., \& Lanf, A. (2009). Statistical power analyses using G*Power 3.1: tests for correlation and regression analyses. Behavior Research Methods, $41,1149-1160$.

Filev, A. (2008). Project management 2.0: the ultimate benefits of the new approach to project management. PM World Today, $X$.

Fishbein, M., \& Ajzen, I. (1975). Belief, attitude, intention and behavior: an introduction to theory and research. Massachussets: Addison-Wesley.

Fornell, C., \& Larcker, D. (1981). Evaluating structural equation models with unobservable variables and measurement error. Journal of Marketing Research, 18(1), 39-50.

Freitas, H., Janissek-Muniz, R., Costa, R., Andriotti, F., \& Freitas, P. (2009). Guia prático Sphinx $\left(1^{\circ}\right.$ ed $)$. Canoas: Sphinx.

Hair, J., Hult, G., Ringle, C., \& Sarstedt, M. (2013). A primer on partial least squares structural equation modeling (PLS-SEM). Sage Publications.

Harris, A. L., \& Rea, A. (2019). Web 2.0 and virtual world technologies: a growing impact on IS education. Journal of Information Systems Education, 20(2), 3.

Horwitz, F., Bravington, D., \& Silvis, U. (2006). The promise of virtual teams: identifying key factors in effectiveness and failure. Journal of European Industrial Training, 30(6), 472-494.

Khanagha, S., Volberda, H., Sidhu, J., \& Oshri, I. (2013). Management innovation and adoption of emerging technologies: The case of cloud computing. European Management Review, 10(1), 51-67.

Khedhaouria, A., Montani, F., \& Thurik, R. (2017). Time pressure and team member creativity within R\&D projects: the role of learning orientation and knowledge sourcing. International Journal of Project Management, 35(6), 942-954.

Kosalge, P., \& Tole, O. (2010). Web 2.0 and business: early results on perceptions of web 2.0 and factors influencing its adoption (p. 208). Apresentado em AMCIS.

Liang, T., Wu, J., Jiang, J., \& Klein, G. (2012). The impact of value diversity on information system development projects. International Journal of Project Management, 30(6), 731739 . 
Likert, R. (1932). A technique for the measurement of attitudes. Archives of Psychology, 22, $140-155$.

Mariani, M. (2020). Web 2.0 and destination marketing: current trends and future directions. Sustainability, 12(9), 3771.

Moore, G., \& Benbasat, I. (1991). Development of an instrument to measure the perceptions of adopting an information technology innovation. Information Systems Research, 2(3), $192-222$.

Orenga-Roglá, S., \& Chalmeta, R. (2019). Methodology for the implementation of knowledge management systems 2.0. Business \& Information Systems Engineering, 61(2), 195-213.

O'Leary, M., \& Cummings, J. (2007). The spatial, temporal, and configurational characteristics of geographic dispersion in teams. MIS Quarterly, 1, 433-452.

O'Reilly, T. (2005). What is web 2.0: design patterns and business models for the next generation of software. Recuperado 2 de outubro de 2016, de Www.oreillynet.com/lpt/a/6228/

Parasuraman, A. (2000). Technology readiness index (TRI): a multiple-item scale to measure readiness to embrace new technologies. Journal of Service Research, 2(4), 307-320.

Parasuraman, A., \& Colby, C. (2001). Techno-ready marketing: how and why your customers adopt technology. New York: The Free Press.

Ribeiro, I. C., \& Pedron, C. D. (2018). Características do gerenciamento de projetos 2.0: um estudo exploratório. Revista Gestão \& Tecnologia, 18(2), 300-320.

Rogers, E. (2003). Diffusion of innovations ( $\left.5^{\circ} \mathrm{ed}\right)$. New York: The Free Press.

Taylor, S., \& Todd, P. (1995). Assessing IT usage: the role of prior experience. MIS Quarterly, 19(2), 561-570.

Thompson, R., Higgins, C., \& Howell, J. (1991). Personal computing: toward a conceptual model of utilization. MIS Quarterly, 15(1), 124-143.

Triandis, H. (1977). Interpersonal behavior. Monterey, California: Brooke/Cole.

Vallerand, R. J. (1997). Toward A Hierarchical Model of Intrinsic and Extrinsic Motivation. In Advances in Experimental Social Psychology (Vol. 29, p. 271-360). Elsevier. https://doi.org/10.1016/S0065-2601(08)60019-2

Venkatesh, V., \& Davis, F. (2000). A theoretical extension of the technology acceptance model: four longitudinal field studies. Management Science, 46(2), 186-204.

Venkatesh, V., Morris, M., Davis, G., \& Davis, F. (2003). User aceptance of information technology: toward a unified view. MIS Quarterly, 27(3), 425-478.

Venkatesh, V., \& Speier, C. (1999). Computer technology training in the workplace: a longitudinal investigation of the effect of the mood. Organizational Behavior and Human Decision Processes, 79(1), 1-28.

Zander, L., Mockaitis, A., \& Butler, C. (2012). Leading global teams. Journal of World Business, 47(4), 592-603. 